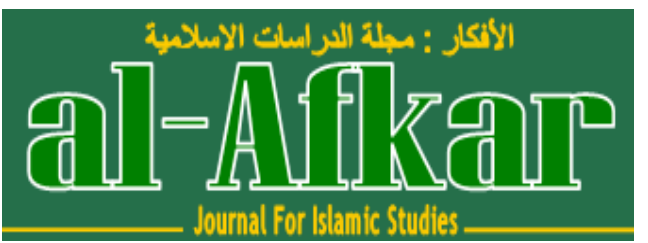

Vol. 2, No. 2, July 2019

P-ISSN : 2614-4883; E-ISSN : 2614-4905

https://al-afkar.com/index.php/Afkar_Journal/issue/view/4

DOI: https://doi.org/10.31943/afkar_journal.v4i1.66

\title{
SELF-SEEKING TOWARDS SELF-KNOWLEDGE IN THE CONFESSIONS' BOOK WRITTEN BY SAINT AUGUSTINE
}

\author{
Abdul Muaz \\ Universitas Muhammadiyah Cirebon \\ E-Mail:muaz@umc.ac.id \\ Hanif Nurcolish Adiantika \\ Universitas Muhammadiyah Cirebon \\ E-Mail:hanifadiantika@gmail.com \\ Sarip \\ Universitas Muhammadiyah Cirebon \\ E-Mail: sarip@umc.ac.id
}

\begin{tabular}{|c|c|c|}
\hline Received & Revised & Accepted \\
\hline 3 Juny 2019 & 20 Juny 2019 & 1 July 2019 \\
\hline
\end{tabular}

\section{SELF-SEEKING TOWARDS SELF-KNOWLEDGE IN THE CONFESSIONS' BOOK WRITTEN BY SAINT AUGUSTINE}

\begin{abstract}
This study aims to investigate Self-Seeking towards Self-Knowledge which plays an essential role for the life moment of the famous and distinguished Christian mystic namely Saint Augustine. He seeks and asks about himself as a human being, both horizontally [his relationship with another man], and vertically [his relationship with God the Creator]. He also reveals the answers toward his questions and searching. It can be explored in his masterpiece entitled 'The Confession'. This study also relies on this book, as the primary reference, to explore and analyze Self-Seeking and SelfKnowledge in Western Mysticism. Therefore, the present study addresses research questions as follow: What is the definition of true Self-Seeking in general? What kind of Self-Knowledge offered by Saint Augustine inside the circumstance of the
\end{abstract}


Western Mysticism Treasury? What is the significance of the Self-Seeking and the Self-Knowledge which is relevant with the current context?

Keywords: self-knowledge, self-seeking, god, light, evil, mysticism, western mysticism, mystic, christian, jesus, christianity.

\section{Introduction}

The Confessions, written by St. Augustine, has always been a reference for for those who are concerned with philosophy, Western theology, and Western Mysticism so far. Martin E. Marty, in The Confession of the introduction of translation, states unsurprisingly that the book has always been listed on "Top 10" or “Top 100" classic best sellers' books for the last two millennia ${ }^{1}$. The masterpiece is deemed to be a great one for some reasons. It involves diverse spiritual topics and themes such as philosophy, love, prayer, worship, faith, sin, light, God, selfknowledge, and so on. The way he reveals his thoughts are indeed personal, honest, and comprehensive. He is so confident in exposing his past, confessing his sins, asking about himself and his faith, until then he reveals and considers himself finding the True Light he has been looking for.

According to various topics, implicitly and explicitly written and documented in the exploration of his intellectual memoirs in 'The Confession' book, the present study attempts to analyze the process of Self-Seeking towards Self-Knowledge proposed by St. Augustine. It is because this theme is fundamental to discuss general mysticism discourse as well as specific Western mysticism. Isn't it right that most mystics ordinarily explore themselves comprehensively? They are great and influential figures who originally have a desire to acknowledge themselves. They want to know their God; would like to explore and deepen their faith to their Creator. They also want to understand their position with the other man, their existence with the True Reality in mortal life. They want to really live up to their existence as servants

For this reason, there are a number of fundamental questions that I propose in this paper: What is the true Self-Seeking and Self-Knowledge in general? Who was Saint Augustine? What kind of Self-Knowledge is offered St. Augustine in the treasures of Western mysticism as he mentioned in the Confessions? What is the significance of the Self-Knowledge to the current context?

To answer the questions above, this paper will discuss four important points. Firstly, presenting a brief biography of Saint Augustine. Secondly, the theme of SelfKnowledge in general. Thirdly, the Self-Knowledge and Self-Seeking of Saint Augustine, which describes the Self-Knowledge conducted in Western mysticism based on The Confessions of Saint Augustine and its significance for today. Fourth, conclusions, namely an overview of Self-Seeking and Self-Knowledge in Saint Augustine and the number of views or suggestions for the readers in the present era. 


\section{Literature Review}

\section{Brief Biography of Saint Augustine}

Saint Augustine was born in Thagaste ${ }^{1}$ on November, 13, 354. His father's name is Patricius, a Pagan who become Christian in the moment of his death in his bed. While his mother's name is Monica, a devout Christian. ${ }^{2}$

Augustine begins his formal education since the age of 11 years. He was sent by his parents to a school in Madaurus, a small town located in the south Thagaste. After that, exactly, when he was 17, he continued his studies in Carthage. Here he is taught about the science of rhetoric. Then, at the age of 20 years, with mistresses and his son, he moved to Rome and then moved to Milan and builded his career as a teacher of rhetoric. ${ }^{3}$

The life of Saint Augustine is not as smooth as the highway: going to school, being a teenager, building a career, getting married, building a family and having children. No. His life is also complicated. Since a teenanger, his personality already appeared with desire of intellectuality and spirituality. History records that, in his youth, he decided a conviction from a man who was born in Christian into Manichaeism believer. ${ }^{4}$ Anyway, too, in his youth, he had to live free and hedonistic; fulfilling his lust with his friends at that time who were called the Subverters. It is recognized by Augustine in The Confessions:

"I kept company with these Subverters and felt a kind of shameless shame for not being like them. I went about with them and there were times when I enjoyed their friendship, though I always hated their actions-that is to say, their "subvertings", which were a kind of wanton persecution of the modesty of ordinary unknown people, a persecution carried out for no reason at all except that by jeering and mocking they were able to give themselves a malicious amusement." 5

Although famous as "impertinence" of his, Augustine is a responsible person. The proof, he retains his relationship with his mistress had given him a boy for more than 15 years. ${ }^{6}$ He recently broke up with her when he returned to Christian while he was in Milan. The pastor who baptized him was Bishop of St. Ambrose, one of the important figures that affect the lives of Augustine later. ${ }^{7}$ Besides St. Ambrose,

\footnotetext{
${ }^{1}$ Harvey D Egan, An Anthology of Christian Mysticism (Liturgical Press, 1991).

${ }^{2}$ Everett Ferguson, Encyclopedia of Early Christianity, vol. 1839 (Routledge, 2013).

${ }^{3}$ Bertrand Russell, "Wisdom of the West," 1959.

${ }^{4}$ Joachim Wach, Sociology of Religion (Routledge, 2019).

${ }^{5}$ Saint Augustine, lo.cit, p.41-42.

${ }^{6}$ Harvey Egan, S.J., lo.cit, p. 57.

${ }^{7}$ Ibid. See also Betrand Russel, lo.cit, p. 134.
} 
important thing that affect the lives of spiritual and mystical way of Augustine is neo-Platonism. ${ }^{8}$

Saint Augustine, who is also known as Augustine of Hippo ${ }^{9}$, died at the age of 76 , on August 28, 430, when the Vandalis besieged his city. ${ }^{10}$ In the tradition of Western mysticism, he was in the category of early Christian mystics who received a Doctor of Church ${ }^{11}$ along with Saint Gregory the Great, Saint Ambrose, and Saint Jerome. $^{12}$

\section{Self-Seeking Towards Self Knowledge}

Self-Seeking is a soul-searching journey that involves a person with himself, the world of internal life, and his Lord. He seeks to find the essence of himself: Who am I? Why am I in this world? For what I was created? What is the true happiness? Because these questions are fundamental and existential, not strange, that the moment of Self-Seeking in order to achieve Self-Knowledge becomes very important. It is philosophical, reflective and spiritual matter. And natural that this behavior is mostly done by philosophers or mystics [Sufis], both in Christian and Islamic tradition. In Islam, as a comparative example, there are Al-Ghazali [born 1058] who pours his struggle and seeking of God in Al-Munqidh min al-Dalal (Deliverance from Error). Al-Ghazali said: "I began by saying to myself: "What I seek is knowledge of the true meaning of things. Of necessity, therefore, I must inquire into just what the true meaning of knowledge is". ${ }^{13}$ In addition to Al-Ghazali, there are also famous among Sufis in East and West named Ibn 'Arabi [born 1165], who seeks and explores himself to know himself and his God. This can be seen in his biography written by Claude Addas, Quest For The Red Sulphur, particularly in chapter 2 [Vocation]. ${ }^{14}$

Meanwhile, in the tradition of Christian mysticism [West], which was present prior to Al-Ghazali and Ibn 'Arabi, many figures who have underwent it, such as Ignatius of Antioch [born 107], Origen [born 184], Basil The Great [born 330], Saint Augustine [born 354] and others. Especially for the last character that I mentioned, Saint Augustine, themes of Self-Seeking and Self-Knowledge becomes an interesting

\footnotetext{
${ }^{8}$ Etienne Gilson, God and Philosophy (Michigan: Yale University Press, 1969), 44-45. I also refer to translation's version of this book in Bahasa, namely: Etienne Gilson, Tuhan di Mata Para Filosof, (Bandung: Mizan, 2004), p. 96.

${ }^{9}$ This nickname is embedded in him because he was ordained as a priest in Hippo [now Annaba], a region in Algeria, by Bishop Valerius of Hippo in 391. The Bishop forced him to accept ordination and to become his assistant. After Valerius's death, Augustine became bishop of Hippo for 35 years. See Harvey Egan, S.J., lo.cit, p.57.

10 Ibid.

${ }^{11}$ In Christian churches, the title of the Doctor of Church means individuals whom they recognize as having been particular importance, particularcly regarding their contribution to theology or doctrine. See Wikipidea.org.

${ }^{12}$ Bertrand Russell, lo.cit. p. 132.

${ }^{13}$ Abu Hamid Al-Ghazali, "Deliverance from Error," Louisville: Fons Vitae, 2000.

${ }^{14}$ Claude Addas, "The Quest for Red Sulphur; The Life of Ibn 'Arabi, Trans," P. Kingsley, Cambridge: Islamic Texts Society, 1993.
} 
issue and a major influence on the history of Western mysticism in later. Many bishops, theologians and mystics of the West after Saint Augustine who inspired and enlightened by his thoughts. Thomas Merton [born 1915], for example, to name West mystics of the 2oth century as an example; he wrote his autobiographical exploration of self and his spirituality in a book entitled The Seven Storey Mountain, and is touted as "the 2oth century Augustine". .15

Basically, what the mystics experienced is the basic character of human being that before themselves also have been done by the prophets, such as Abraham, Moses, Jesus, and Muhammad. Or also by the Greek philosophers such as Plato, Socrates, and Aristotle.

In this case, every human being should also investigate the existence of himself: Who am I? Why was I born? Who is my God? And so on. ${ }^{16}$ Or it could also start following questions such as Saint Augustine: "What are you [Lord] to me? What am I to you? O Lord, my God, tell me what you are to me?"17

Unfortunately, with the changing periods and history, the character of SelfSeeking to determine the nature of Self-Knowledge slowly disappearing, drowning in information and technology trends that often alienates man from himself.

\section{Self-Seeking and Self-Knowledge in The Confessions of Augustine}

As I mentioned above, discussing this theme in the tradition of Western mysticism, one figure must be referred is Saint Augustine. Moreover, when we read the pages of his monumental work titled: The Confessions. ${ }^{18}$ In the book, it is so tasty the aura of Self-Seeking of Saint Augustine in order to know the existence of himself, to understand his heart and his faith to the Lord. Since the beginning of the page, he already told us about it. Let us see his following words:

"Our hearts are restless until they can find peace in You. Grant me, O Lord, to know and understand which should come first, prayer or praise; or, indeed, whether knowledge should precede prayer. For how can one pray to you unless one knows you?"19

Typically, this step proceeds and grows according to the intellectual and spiritual experiences of each mystic. There is who experienced in his early age such

\footnotetext{
${ }^{15}$ Thomas Merton, The Seven Storey Mountain (New York: Harvest Books Harcourt, Brace and Company, 1999), p. 1-20.

${ }^{16}$ Louis P. Pojman, Who Are We? Theories of Human Nature (Oxford: Oxford University Press, 2006), p.1-5 [lihat lagi].

${ }^{17}$ Saint Augustine, lo.cit, p. 4.

${ }^{18}$ This classic work was contained in 13 books and talked from a little Augustine to maturity of him.

${ }^{19}$ Saint Augustine, lo.cit, Book 1-1, p. 1.
} 
as Ibn 'Arabi, or vice versa ${ }^{20}$. But, certainly, it depends on their will and anxiety in their experiences. There is a dialectic that grow slowly in their soul. There is a dialectic of meaning and event that accompany their seeking.

And Saint Augustine experienced it since he decided to return to the Christian faith. As we know, he is from birth to be baptized in the Christian faith, but was not satisfied and choose Manichaeism, and then out again from Manichaeism and choose Christian teachings with deeper perspectives.

For Augustine, the philosophy of dualism where God has two powers: God of light and God of darkness as predicted the Manichean unable to answer his restlessness, unable to reveal his philosophical questions, especially the problem corporeality of God and the problem of evil. ${ }^{21}$ He uttered this problem in The Confessions:

"I would certainly say and I firmly believe that you-our Lord, the true God, who made not only our souls and bodies, and not only our souls and bodies but all men and all things-were undefilable and unalterbale and in no way to be changed, and yet I still could not understand clearly and distinctly what was the cause of evil. Whatever it might be, however, I did realize that my inquiry must not be carried out along lines which would lead me to believe that the immutable God was mutable; if I did that, I shoud become myself the very evil which I was looking for. And so I pursued the inquiry without anxiety, being quite certain that what the Manichees said was not true. I had turned against them with my whole heart, because I saw that in their inquiries into the origin of evil they were full of evil themselves; for they preferred to believe that your substance could suffer evil rather than that their substance could do evil."22

His great attention to the aspect of evil is quite reasonable. The background of his life as a teenager has been in contact with the "dark" behavior--he thought-is not right and wrong.

He was so far-along with his friends-experienced a hedonistic life with superficial physical desires beginning to realize his faults. And he did not find any religious and philosophical solutions for his problems and anxiety in Manichaeism. No wonder, when described his misleading adolescence, he was very sorry and prayed with humility:

\footnotetext{
${ }^{20}$ Metode Racut and Dalam Tasawuf, “Metode Racut Dalam Tasawuf Jawa;," no. December (2017): 126-32, https://doi.org/10.5281/zenodo.1255216.

${ }^{21}$ Louis P. Pojman, lo.cit, p. 72.

${ }^{22}$ Saint Augustine, op.cit, Book VII-3, p. 127.
} 
"What shall I render unto the Lord because, while my memory recalls these things, my soul is not terrified at them? I will love Thee, O Lord, and thank Thee and confess unto Thy name, because you have forgiven me these great sins and these evil doings of mine. To your grace I owe it, and to your mercy, that you have melted away my sins like ice. And to your grace too I owe the not doing of whatever evil I have not done." ${ }^{23}$

Slowly, Augustine life began to change. Especially, when he moved to Milan in 385 , a city known as a center of intellectual in the moment. In this city he also met with Bishop Ambrose. The influence of this figure was so important in spiritual searching of Augustine. He listened sermons of Ambrose, and slowly began to question and deny Manichaism teachings, particularly what he got from Faustus, an important figure in Manichaism. In Confessions [Book V-13], Augustine explained:

"At Milan, I came to Bishop Ambrose, who had a worldwide reputation..... man whose eloquence in those days gave abundantly Thy people the fatness of Thy wheat, the gladness of Thy oil and the sober intoxication of Thy wine. Though I did not realize it...I might be led to you by him....I began to love him at first not as a teacher of the truth (for I had quite despaired of finding it in your Church) but simply as a man who was kind and generous to me. I used to listen eagerly when he preached to the people.....I much pleased by the the charm of his style, which although it was more learned, was still, so far as the manner of delivery was concerned, not so warm and winning as the style of Faustus. With regard to the actual matter there was, of course, no comparison. Faustus was merely roving around among Manichaean fallacies, while Ambrose was healthily teaching salvation." ${ }^{24}$

Well, can not be denied, the milieu affects the life of human being. In Milan, besides meeting Ambrose and switch into catechumen of Catholic churh, he began to learn a lot of neo-Platonism teachings ${ }^{25}$ and others which broaden his horizon, enrich his Self-Seeking and Self-Knowledge. ${ }^{26}$ The philosophical puzzles that became his askings revealed the answer in neo-Platonism teachings. In neo-

\footnotetext{
${ }^{23}$ Ibid, Book II-7, p.35.

${ }^{24}$ Ibid, Book V-13, p. 96-97.

${ }^{25}$ Neo-Platonism is established by Plotinus [born 204], a major philosopher in ancient world. He continued the Platonic tendency of identifying the God and the One, and of situating the Good or the One "beyond being", which for Plotinus meant about the Platonic ideas. The mind, which involves a distinction of knowing subject and known object, was located below the One. Thereby, repudiating Aristoteles's assertion that the first principle think itself. Plotinus's concept of the Divine and its relation to other things is contained in the Enneads. See George F. McLean and Patrick J. Aspell, Ancient Western Philosophy: The Hellenic Emergence (Washington D.C.: The Council for Research in Values and Philosophy, 1997), p. 271-277. In Bahasa, you may also see in DR. K. Bertens, Ringkasan Sejarah Filsafat (Yogyakarta: Penerbit Kanisius, 1992), p. 18-19.

${ }^{26}$ Louis P. Pojman, ibid.
} 
Platonism philosophy, he was impressed and enlightened in term of invisible Being, of goodness and its forms, which can be experienced by the mind. Augustine found that the ideas of neo-Platonism can explain Christianity, something that strengthen his faith day by day. He increasingly believes that the true knowledge is spiritual, absorb ideas by mind, not senses. ${ }^{27}$ Augustine said: "After reading these bookss of Platonists which taught me to seek for a truth which was incorporeal, I came to see your invisible things, understood by those things which are made..." ${ }^{28}$

No wonder, if Augustine's teaching is similar to Plato and Plotinus that all things was immaterial, intelligble, and true was divine in its own right. ${ }^{29}$ For all that it produced by thought that God such as "intelligble sun whose light shines upon human reason and enables it to know truth; He is the inner master who teaches man from within; his eternal and unchangeable ideas are the supreme rules whose influence submits our reason to the necessity of divine truth." ${ }^{\circ}$

According to Saint Augustine, seems clearly, if a man want to find himself and know himself, all the answers located in the deepest of his heart. Because, in man himself, there is a divine element that used potentially will guide himself to find his askings and puzzles.

This means, which Platonic's ideas, Augustine concluded that human being has limitations in grasping the True Knowledge and Light. Man has limits in his life which the reason and senses could not reach it. It became his mystical experience. Therefore, said Augustine, faith stands higher than reason. ${ }^{31}$ It increasingly explained that Self-Knowledge becomes personal dan individual. Do not "we know a thing not because of the external evidence of our senses that is hared by others, but because of inner intuition, which represents the infusion of grace into our persons? Because Augustine conceived of knowledge in this way, it is hardly surprising that he distrusted systematic reason. The clarity and coherence of formal logic was deceptive, whereas the complexity of personal experience represented true reality." ${ }^{2}$ Do not you realized that mystics has experienced it, whether in Western mysticism tradition or Eastern [Islam]?

\section{The Significance of Self Seeking for Self-Knowledge}

In New Testament [Acts 17:24-29], St. Paul, one of the Apostles who taught the gospel of Christ, the figure who inspired the Christianity of Augustine in Confessions, mentioned the importance of Self-Seeking:

\footnotetext{
${ }^{27}$ Ibid. See also Etienne Gilson, lo.cit, p. 44-45.

${ }^{28}$ Saint Augustine, loc.cit, Book VII-20, p. 146.

${ }^{29}$ Etienne Gilson, op.cit, p. 57.

${ }^{30}$ Ibid, p.59.

${ }^{31}$ Donal J. Wilcox, In Search of God and Self (Boston: Houghton Mifflin Company, 1975), p. 233.

32 Ibid, p. 234.
} 
"The God, who made the world and all things in it...made from one blood every nation of men...that they should seek the Lord, if perhaps they might reach out for him and find him, though he is not far from each one of us. For in him, we live and move and have our being, as some of your own poets have said, "For we also are his offspring.."33

Paul messages delivered that Self-Seeking to know God and Self-Knowledge is something highly recommended. Indeed, as far as my observation, Augustine himself based his Self-Seeking and Self-Knowledge is not out of Scripture. Moreover, he put the words of Scripture as a weapon to justify his philosophical searching. Well, not weird, if Brian Stock wrote: "What distinguishes him from purely philosophical thinkers on this issue is the link that he perceives between selfknowledge and an appreciation of God's word, in which the reading of Scripture plays a previleged role." 34

Indeed, in far away days, Jesus asserted in his words about his longing to be found and known by his followers. Therefore, it is natural if Augustine referred him as the most important foundation, namely His words and faith in Him. Let see what Jesus said:

"I have come as a light into the world, that whoever believes in me may not remain in the darkness. If anyone listens to my sayings, and doesn't believe, i don't judge him. For I come not to judge the world, but to save the world. .." [John, 12: 46-47]. ${ }^{35}$

"I am the light of the world. He who follows me will not walk in the darkness, but will have the light of life " $[\text { John, 8: 12] }]^{36}$

That is why, Augustine--as a man was sinful and evil, who want to embrace the true happiness and peace along with his Lover-often mentioned about searching of true Light, the Truth, is a way towards the True-Knowledge. It can bring someone closer to the Truth. Let see Augustine words in following messages:

"He who knows the truth knows that light, and he who knows the light knows eternity. Love knows it. O, eternal truth and true love and beloved eternity, you are my God; to you I sigh by day and by night..."37

\footnotetext{
${ }^{33}$ The New Testament+Psalms\&Proverbs of the World English Bible (Colorado: Rainbow Mission Inc, 2008), p. 138.

${ }^{34}$ Brian Stock, Augustine The Reader: Meditation, Self-Knowledge, and The Ethics of Interpretation (USA: Harvard University Press, 1998), p. 273

${ }^{35}$ See The New Testament, lo.cit, p. 107.

${ }^{36}$ See The New Testament, ibid, p. 100.
} 
"For when I seek you, my God, I am seeking the happy life. I will seek thee Thee, that my soul may live. For my body lives by my soul, and my soul lives by you..." ${ }^{8} 8$

"We have the promise; no one can alter or distort it: if God be for us, who can be against us? Ask, and ye shall have; seek, and ye shall find; knock, and it shall be opened unto you. For every one that asketh, receiveth, and he that seeketh, findeth, and to him that aknocketh, it shall be opened. These promise are yours, and when truth makes the promise, who can fear deception." 39

Augustine and his meaningful treatise, the Confessions, want to invite everyman and woman, not only for Christians, but also for others, to find and know about the origin of himself till he really realize that human being without understanding Self-Knowledge to effect to the self-alienation. He becomes fragile and finally brings into darkness; no light, no knowledge.

Especially in modern context--when many people lost of the self-concept in the jungle of images among information society, which offering the variety of pseudo self-concept [through advertising, movies, soap opera, and so on] -a man will keep away from himself, from his existence. Because he forgot to know his true existence. ${ }^{40}$ Everything became instant and moved fastly in contemporary society. DR. Yasraf Amir Piliang, an Indonesian scholar who concerned with this issue-wrote: "Duration and time of life become faster, but the faster it is, the more of fatalism and emptiness is. Because life is spent with work and pleasure cycle that run by rapid time, so therefore it will trap human being in its rhythm of acceleration, and the other hand it will increasingly limit time and space for seeking a meaningful and spiritual life." ${ }^{41}$ In Indonesia today, this phenomenon increasingly prevalent day by day. It not only occured and entered in urban society but also in rural society. Ironically, this is the case in the country that its people practiced religion and require a religion sign in the Citizenship Identity Card [KTP].

If analyze this phenomenon, I remembered of Kierkegard, an extentialist philosopher, who divided three stages of human condition: aesthetic, ethic, and religious. In modern society, who love hedonistic things, who often persuaded by information and technology imaging seduction, there are a number of men or women who are at the aesthetic stage, namely a stage where the orientation is fully geared to delight of his life, in order to satisfy his sexual instincts, hedonistic and based on his mood. People who live in this stage is without soul, having no root and

\footnotetext{
${ }^{37}$ Saint Augustine, lo.cit, Book VII-10, p. 139.

${ }^{38}$ Ibid, Book X-20, p.223.

${ }^{39}$ Ibid, Book XII-1, p.281.

${ }^{40}$ Yasraf Amir Piliang, Sebuah Dunia Yang Dilipat: Realitas Kebudayaan Menjelang Milenium Ketiga dan Matinya Posmodernisme, (Bandung: Mizan, 1998), p. 32.

${ }^{41}$ Ibid, p. 125.
} 
content in the soul. ${ }^{42}$ They did not enter an ethical stage, namely start accepting the moral wisdoms and choose to tie their soul in them. ${ }^{43}$ Moreover, they forgot a religious stage, namely the stage not only in the formal worship, but also jump and really melt into Divine reality. If an ethical stage still use rational considerations to execute, a religious stage no need reason and any rational and scientific considerations to undergo. It takes only a subjective belief based on faith. ${ }^{44}$ At his level, a faithful man will be called an authenthic human. And the effort of Augustine as described in the Confession, in my opinion, is to invite a religious person to be an authenthic human as Kierkegard explained above.

Therefore, although Saint Augustine and his foremost work, The Conffesions, lived centuries ago, but his important messages about Self-Seeking toward SelfKnowledge is still relevance, significance and meaningful.

\section{Conclusion}

The discussion of Self-Seeking in order to achieve Self-Knowledge is not a strange theme to the religious life of Christian. It does not belong to the tradition of Western mysticism alone. A long time ago, Jesus and His followers already proclaimed it in order to be happy and peaceful people.

Saint Augustine as written embodied in his work, The Confessions-- is one of the important figures who discuss this matter. His life before becoming a bishop and Western mystics based on his honest and stunning Self-Seeking. Not strange, he inspired many Christian and other human figures.

In the present context, this theme will remain relevant and very important. Moreover, many people are uprooted and alienated themselves, who lost their authentic existence due to drift in the flow of information and technology that is shallow and superficial.

\footnotetext{
${ }^{42}$ Zainal Abidin, Filsafat Manusia: Memahami Manusia Melalui Filsafat (Bandung: Rosdakarya, 2003), p. 134.

${ }^{43}$ Ibid, p. 135.

${ }^{44}$ Ibid, p. 136.
} 


\section{REFERENCES}

Addas, Claude. “The Quest for Red Sulphur; The Life of Ibn 'Arabi, Trans.” P. Kingsley, Cambridge: Islamic Texts Society, 1993.

Al-Ghazali, Abu Hamid. “Deliverance from Error.” Louisville: Fons Vitae, 2000.

Egan, Harvey D. An Anthology of Christian Mysticism. Liturgical Press, 1991.

Ferguson, Everett. Encyclopedia of Early Christianity. Vol. 1839. Routledge, 2013.

Racut, Metode, and Dalam Tasawuf. "Metode Racut Dalam Tasawuf Jawa;" no. December (2017): 126-32. https://doi.org/10.5281/zenodo.1255216.

Russell, Bertrand. "Wisdom of the West," 1959.

Wach, Joachim. Sociology of Religion. Routledge, 2019.

Abidin, Zainal, Filsafat Manusia: Memahami Manusia Melalui Filsafat (Bandung: Rosdakarya, 2003).

Brightman, Edgar Shieffield, A Philosophy of Religion (New York: Prentice-Hall, 1947).

Egan, Harvey, S.J., An Anthology of Christian Mysticism (Minnesota: The Liturgical Press, 1991).

Ferguson, Everet,, Encylopedia of Early Christianity (New York: Garland Publishing, 1997).

Gilson, Etienne, God and Philosophy (Michigan: Yale University Press, 1969).

Gilson, Etienne, Tuhan di Mata Para Filosof, (Bandung: Mizan, 2004).

McLean, George F. and Aspell, Patrick J., Ancient Western Philosophy: The Hellenic Emergence (Washington D.C.: The Council for Research in Values and Philosophy, 1997).

Merton, Thomas, The Seven Storey Mountain (New York: Harvest Books Harcourt, Brace and Company, 1999).

Piliang, Yasraf Amir, Sebuah Dunia Yang Dilipat: Realitas Kebudayaan Menjelang Milenium Ketiga dan Matinya Posmodernisme, (Bandung: Mizan, 1998).

Pojman, Louis P., Who Are We? Theories of Human Nature (Oxford: Oxford University Press, 2006).

Stock, Brian, Augustine The Reader: Meditation, Self-Knowledge, and The Ethics of Interpretation (USA: Harvard University Press, 1998)

The New Testament+Psalms\&Proverbs of the World English Bible (Colorado: Rainbow Mission Inc, 2008).

Wilcox, Donal J., In Search of God and Self (Boston: Houghton Mifflin Company, 1975). 